\title{
Improvement of supply chain performance of printing services company based on supply chain operation references (SCOR) model
}

\author{
Zulfa Fitri Ikatrinasari ${ }^{a^{*}}$, Nanang Harianto ${ }^{a}$ and Eka Indah Yuslistyari ${ }^{b}$
}

${ }^{a}$ Industrial Engineering Study Program, Universitas Mercu Buana, Jakarta, Indonesia

${ }^{b}$ Industrial Engineering Study Program, Universitas Serang Raya, Banten, Indonesia

\begin{tabular}{l}
\hline C H R O N I C L E \\
\hline Article history: \\
Received April 20, 2020 \\
Received in revised format June \\
8,2020 \\
Accepted June 102020 \\
Available online \\
June 102020 \\
\hline Keywords: \\
Supply chain \\
SCOR \\
Performance
\end{tabular}

\begin{abstract}
Supply chain is the most important factor in increasing competitiveness since the biggest cost of a product is in the supply chain. PT. EJI is a printing and merchandising Services Company that has several suppliers and almost all processes are inseparable from the supply chain system. Supply chain problems at PT EJI are in the production process, delivering orders, PO In and PO Out. Repairing the supply chain can be accomplished through the Supply Chain Operation Reference (SCOR) Method. This study recommends improving supply chain based on the results of performance measurement with the SCOR method which consists of 4 performance criteria, namely: 1) Reliability Criterion: Perfect Order Fulfillment (POF); 2) Responsiveness Criterion: Order Fulfillment Cycle Time (OFCT); 3) Cost Criterion: Cost of Goods Sold (COGS); 4) Assets Criterion: Cash to Cash Cycle Time (CTCCT). The results of the performance measurement show that the delivery process was 80.0 , which is the lowest compared with other metrics, namely Make 99.0 and Source 95.0. Supply Chain improvement recommendations are shipping improvements (delivery) through the separation of shipping routes for shipping Online and Offline, checking the quality of invoice documents to avoid incomplete documents, making SOPs for shipping, and providing dietary at the time of delivery to avoid mismatching goods.
\end{abstract}

\section{Introduction}

Organization must adapt to the changing business environment quickly and make strategic decisions that are suitable for organization, compete effectively, improve performance through quality improvement, minimize costs, and produce different products and services with other competitors (Kosasih et al., 2020). Over the past few years, the advantages of supply chain optimization and integration have been the focus of several large corporate organizations in the world. There has been an increase in business competition and rapid technological development. There is a high level of business competition in various industrial fields, especially the merchandise printing service industry where there is an increase in the company's competitiveness in the form of increased efficiency and productivity. One of the ways to improve efficiency is by integrating the company's supply chain activities, so there are no difficulties in the supply chain operational planning process (Mutakin \& Hubeis, 2011). The concept of supply chain management SCM (Supply Chain Management) is capable of integrating the management of various management functions in inter-organizational relationships to form an integrated system and support each other. The key to have effective SCM is to help suppliers in the company's strategy meet an ever-changing market (Heizer \& Render, 2005).

Theories and practices in supply chain management have been widely applied to companies both large and small. However, apparently the application of existing SCM still faces problems including not being able to efficiently and effectively manage and maintain suppliers, in order to remain loyal to the company. One company that has implemented the SCM concept is PT. EJI. This company, which is engaged in printing and merchandising services, has several suppliers whose almost all processes are inseparable from the supply chain system, which also has the same problem. One of SCM's performance measurements is the Supply Chain Operation Reference (SCOR) model, which is designed by the Supply* Corresponding author 
Chain Council (SCC) and can measure good supply chain management control between suppliers, companies and customers. In this case, there are several versions of SCOR. At present SCC has released version 12 of the SCOR model (www.supply-chain.org). The SCOR model is one of the supply chain operations models, which is a process-based model that integrates three (3) main elements in management, namely Business Process Reengineering (BPR), Benchmarking and Best Practice Analysis (BPA) into the cross-supply framework. SCOR divides supply chain processes into five (5) core processes, namely plan, source, make, deliver and return. SCOR has three (3) levels of process from general to detailed (Bol-stroff \& Rosenbeum, 2013). According toWahyuniardi et al. (2017) most measurements use the SCOR approach to the hierarchical model at the beginning adjustment of company conditions. While normalization functions to equalize the matrix can also be used as an indicator of the measurement. According Wibowo and Sholeh (2015) Supply Chain plays an important role in the process of material flow from the supply of raw materials by suppliers to finished products into the hands of consumers; which is to determine the extent to which the company's supply chain performance has been achieved. In improving supply chain performance, there are 3 improving tools are required; namely quality campaign, shop floor improvement and cost control management according to Rakhman et al. (2018).

The purpose of this study is to determine the appropriate indicators and measurement of performance using SCOR on a printing services company, calculate the performance of SCM and then provide recommendations for improvements to increase performance SCM.

\section{Literature Review}

\subsection{Supply Chain Management (SCM)}

The term Supply Chain Management in the business world is often identified with logistics and operation management. However, the service-based business activities in the SCM process is how consumers are satisfied with the performance results of a service company or can also be interpreted as a series or network of companies that work together to create and distribute products or services to end customers. In general, existing efforts put more emphasis on improving performance in the process. Simchi-Levi et al. (2000) defines SCM as an approach used to achieve efficient integration of suppliers, manufacturers, distributors, retailers, and customers. Pires et al. (2001) define SCM as a network of suppliers, manufactures, assembly, distribution, and logistical facilities that shape the purchasing function of materials, transformation of materials into semi-finished and finished products, and the distribution process of products to consumers.

Heizer and Rander (2008) define SCM as the activity of managing activities in order to obtain raw materials into process goods or semi-finished goods and finished goods then send the product to consumers through a distribution system. Chow et al. (2006) define SCM as a holistic and strategic approach in terms of demand, operations, purchasing, and management of logistics processes. The concept of supply chain management is managing the flow of goods from upstream to downstream or from producers to customers. The flow of goods applies in the same direction from producers to consumers. Supply chain management is an integrated method, tool or approach for managing the flow of products, information, and money in an integrated manner involving parties ranging from upstream to downstream consisting of suppliers, factories, distribution networks and logistics services (Ghassemi et al., 2018). According to Heizer and Render (2008), supply chain also includes all interactions between suppliers, producers, distributors and customers. This chain includes transportation, planning information, money transfers by credit or cash, as well as the transfer of ideas, designs and materials.

\subsection{Supply Chain Operation Reference (SCOR) Method}

In 2002, the Supply Chain Council (SCC) introduced and developed a known supply chain performance measurement (SCOR) that was developed to describe the management process associated with all phases involved to meet customer demand. There are five main supply chain management processes defined in this model, namely: plan, source, make, deliver, and return. SCOR is developed and supported by an independent non-profit organization called the Supply Chain Council (SCC). The SCC Institute is the PRTM consulting agency and McGrath from AMR Research. (Basheer et al., 2019). SCC has been developed because of the formation of a consortium of 70 practitioners from companies located in West America. In general, industry practitioners define SCM as a definition of the desired processes and measurements between consumers and suppliers. The SCOR model is a standard model that can be used as a guide in the expansion of information between elements in the SCM.

The ability of the SCOR model is to define the relationship between the process and demand elements. SCOR models are based on descriptions that occur in supply chains with approaches between organizations, industry segments and geographies. These five management processes are broken down into three levels of detail. At level one, SCOR performance can be directly applied to the organization's business goals. Level two and three process elements explain in more detail the activities in order to give a broader shift into SCOR operations. Because this model encompasses organizations and each organization is unique, the model must be extended to level four. According to Ul-Hameed et al. (2019), in terms of 
increasing the ability to understand and manage, the SCOR model describes into five dimensions, namely reliability, responsiveness, flexibility, cost and efficiency of asset use. As the hierarchy is structured in the process, it also makes it easier for us in SCM and sets out measurements to test certain elements of performance within SCOR elements.

Table 1

Prior Research

\begin{tabular}{|c|c|c|c|}
\hline No & Author & Method & Results and Conclusions \\
\hline 1 & $\begin{array}{l}\text { Wahyuniardi et } \\
\text { al. (2017) }\end{array}$ & $\begin{array}{l}\text { Supply } \\
\text { Chain } \\
\text { Operation } \\
\text { Reference } \\
\text { (SCOR) } \\
\text { Model }\end{array}$ & $\begin{array}{l}\text { The study was conducted to measure the performance of the company's supply chain using the Supply Chain Operation } \\
\text { References (SCOR) approach. The initial hierarchy model of performance measurement is adjusted to the condition } \\
\text { of the company to measure the performance of its supply chain, while the normalization of Snorm De Boer serves to } \\
\text { equalize the matrix value used as an indicator of measurement. The importance of performance attributes is measured } \\
\text { by weighting with subjective questionnaires. The value of the performance attributes obtained reliability } 19.74 \text {, } \\
\text { responsiveness } 16.91 \text {, agility } 11.00 \text {; and asset management } 12.26 \text {. The total value of performance is } 59.90 \text {. This value } \\
\text { shows that the company's supply chain performance is in an average position. }\end{array}$ \\
\hline 2 & $\begin{array}{l}\text { Wibowo and } \\
\text { Sholeh (2015) }\end{array}$ & $\begin{array}{l}\text { Supply } \\
\text { Chain } \\
\text { Operation } \\
\text { Reference } \\
\text { (SCOR) } \\
\text { Model }\end{array}$ & $\begin{array}{l}\text { According to research on canned companies using the SCOR method, the value of the achievement of the company's } \\
\text { overall supply chain performance is } 7.48 \text {. By weighting using AHP and calculating the scoring system using OMAX, } \\
\text { it can be seen } 2 \text { supply chain performance indicators that need to immediately get corrective action, namely indicators } \\
\text { that are in the red category, namely the percentage level of deviation of actual demand with the number of production } \\
\text { plans with a value of } 3.34 \text { and the effectiveness of periodic checking machines with a value of } 3.38 \text {. Making } \\
\text { improvements to these indicators is expected to help improve supply chain performance in the company. }\end{array}$ \\
\hline 3 & $\begin{array}{l}\text { Rakhman et } \\
\text { al. (2018) }\end{array}$ & $\begin{array}{l}\text { Supply } \\
\text { Chain } \\
\text { Operation } \\
\text { Reference } \\
\text { (SCOR) } \\
\text { Model }\end{array}$ & $\begin{array}{l}\text { Supply chain actors at PT. XYZ consists of suppliers, subcontracted materials, } \\
\text { PT. XYZ, subcont services finishing, customer OEM, customer simplification, customer export, and customer after- } \\
\text { market. The results of measurements at the level of performance attributes are Reliability ( } 92 \% \text { - Excellent ), } \\
\text { Responsiveness }(70 \% \text { - Average ), Flexibility ( } 71 \% \text { Good }) \text {, Cost }(71 \%-\text { Good }) \text {, and Asset }(60 \% \text { - Average }) \text {. In } \\
\text { improving supply chain performance at PT. XYZ has to do with } 3 \text { improve tools namely, quality } \\
\text { campaigns, shopfloor improvement, and management cost control. }\end{array}$ \\
\hline 4 & $\begin{array}{c}\text { Irfan et } \\
\text { al. ( 2008) }\end{array}$ & $\begin{array}{l}\text { SCOR } \\
\text { Model }\end{array}$ & $\begin{array}{l}\text { This paper presents supply chain management efforts, key challenges and opportunities in the industry sector and the } \\
\text { most successful organizations in Pakistan and the business chain 'from seed to smoking' using a leading supply chain } \\
\text { operations reference model. }\end{array}$ \\
\hline 5 & $\begin{array}{l}\text { Georgise et } \\
\text { al. (2013) }\end{array}$ & $\begin{array}{l}\text { Supply } \\
\text { Chain } \\
\text { Operation } \\
\text { Reference } \\
\text { (SCOR) } \\
\text { Model }\end{array}$ & $\begin{array}{l}\text { This paper discusses the implementation of best practices and challenges encountered during the adoption } \\
\text { process. Research methodologies include literature review, questionnaire surveys and semi-structured } \\
\text { interviews. Ethiopian manufacturing companies were sampled for empirical studies. The research survey is based on } \\
\text { the best practices of the SCOR model. The findings show that most of the respondent companies have shown interest } \\
\text { and are trying to implement some of them. But, the results are below expectations. The adoption of best practices has } \\
\text { faced various challenges and the unavailability of required supporters. Therefore, there is a need for developing } \\
\text { countries to analyze their scenarios and then adapt best practices that take into account their real situations. }\end{array}$ \\
\hline 6 & $\begin{array}{c}\text { Jamehshooran et } \\
\text { al. (2015) }\end{array}$ & $\begin{array}{l}\text { SCOR } \\
\text { Model }\end{array}$ & $\begin{array}{l}\text { The results revealed a significant positive relationship between business analysis and supply chain performance. This } \\
\text { study combines resource-based theory; resource dependency theory develops a new theoretical framework to } \\
\text { demonstrate the importance of business analysis; in improving supply chain performance. }\end{array}$ \\
\hline 7 & $\begin{array}{l}\text { Zhou et } \\
\text { al. ( 2011) }\end{array}$ & $\begin{array}{l}\text { Supply } \\
\text { Chain } \\
\text { Operation } \\
\text { Reference } \\
\text { (SCOR) } \\
\text { Model }\end{array}$ & $\begin{array}{l}\text { The purpose of this study is to empirically validate the SCOR model (eg, test the structure of the SCOR model). Data } \\
\text { from } 125 \text { North American manufacturing companies was collected. The results show that the relationship between } \\
\text { supply chain processes in the SCOR model is generally supported. The Plan process has a significant positive effect } \\
\text { on the Source, Make, and Deliver processes. The Source process has a significant positive effect on the Make process } \\
\text { and the Make process has a significant positive effect on the Deliver process. The Source process mediates the impact } \\
\text { of the Plan process on the Make process and the Make process mediates the impact of the Plan process on the Deliver } \\
\text { process. This finding provides empirical evidence to managers that the SCOR model is valid. }\end{array}$ \\
\hline 8 & $\begin{array}{l}\text { Sutawijaya \& } \\
\text { Marlapa (2018) }\end{array}$ & $\begin{array}{l}\text { SCOR } \\
\text { Model }\end{array}$ & $\begin{array}{l}\text { This study analyses the application of the Supply Chain Operation Reference Model (SCOR) at PT. Indoturbine. Based } \\
\text { on the stages of the process contained in each section on level } 1 \text { chain supply there are some processes that experience } \\
\text { errors. This research shows that the supply chain conditions at PT. Indoturbine is less efficient because of measurement } \\
\text { metrics owned by PT. Indoturbine especially the POF and OFCT values are below the median value the industry is the } \\
\text { Advantage Data Benchmark value. The comparison is as following: POF value of } 64.03 \% \text { while the value of the POF } \\
\text { Advantage Data Benchmark is } 71.8 \% \text { while OFCT value is } 92 \text { days while OFCT Advantage Data value Benchmark } \\
\text { of } 90 \text { days. }\end{array}$ \\
\hline 9 & $\begin{array}{l}\text { Kasi } \\
(2005)\end{array}$ & $\begin{array}{l}\text { Supply } \\
\text { Chain } \\
\text { Operation } \\
\text { Reference } \\
\text { (SCOR) } \\
\text { Model }\end{array}$ & $\begin{array}{l}\text { This paper aims to discuss one aspect of SCOR while at the same time giving a brief description of the concept and } \\
\text { its use. Specifically, we examine SCOR from a methodological perspective, by adopting a system development } \\
\text { framework and using a social-technical lens as a basis for assessment. To carry out such an assessment, a fictitious } \\
\text { corporate time instrument (Timewise) tool is used to create the context for developing and assessing SCOR } \\
\text { approaches. It was found that SCOR is strong in technical dimensions such as modelling processes and techniques but } \\
\text { weak in social dimensions. Contributions from this paper include an overview of SCOR and systemic assessment } \\
\text { methods for developing SCOR models to highlight the strengths and limitations of the approach and to guide future } \\
\text { research in this domain. }\end{array}$ \\
\hline 10 & $\begin{array}{c}\text { Rahayu \& } \\
\text { Kusumah (2017) }\end{array}$ & $\begin{array}{l}\text { SCOR } \\
\text { Model }\end{array}$ & $\begin{array}{l}\text { Company performance can be measured in two perspectives, financial and non-financial. Current conditions, PT API } \\
\text { as a manufacture of ready-to-drink juice (RTD) drinks is more focused only on financial measures. Weakness financial } \\
\text { performance is less able to measure operating performance. The supply chain is one of the most operations important } \\
\text { as one measurement of non-financial performance. The purpose of this study is to measure performance the supply } \\
\text { chain of PT API using SCOR as a performance measurement framework. From data quantitative, obtained value of } \\
\text { supply chain measurement of PT. API is } 61.85 \text {, which means Supply chain performance at PT. The API is not yet } \\
\text { included in the category of good performance or still at an average level. }\end{array}$ \\
\hline
\end{tabular}

\subsection{Measurement of Supply Chain Performance Based on the SCOR Model}

The Supply Chain Operation Reference is abbreviated as SCOR model. One way to understand the supply chain is to use a process model. The Supply Chain Council created the SCOR model as a way for companies to communicate. More than 400 companies use the SCOR model to understand and improve their supply chains. Aerospace companies include producers and defense, large consumer product manufacturers, and third-party logistics providers. SCOR combines several elements namely Business Process Engineering, benchmarking and applications that lead to a framework. One of SCM's performance measurements, the Supply Chain Operation Reference (SCOR) model, a model designed by the Supply-Chain Council (SCC), can measure good supply chain management controls between suppliers, companies and customers. In this 
case, there are several versions of SCOR. At present SCC has released version 12 of the SCOR model (www.supplychain.org). The SCOR model is one of the supply chain operations models, which is a process-based model that integrates three (3) main elements in management, namely Business Process Reengineering (BPR), Benchmarking and Best Practice Analysis (BPA) into the cross-supply framework. SCOR divides supply chain processes into five (5) core processes, namely plan, source, make, deliver and return. SCOR has three (3) process levels from general to detailed (Alzoubi et al., 2019). The process in SCOR consists of 3 levels. Level 1 is a top level consisting of 5 key processes namely Plan, Source, Make, Deliver and Return. Level 1 metrics characterize performance based on two perspectives. The first perspective is from the customer side and the second perspective is based on an internal perspective. At this level, a definition of the basic competition to be achieved is carried out along with instructions and ways to meet the basic competition. Level 2 is the Configuration Level and is closely related to the categorization of processes. At level 2, defining the categories of each process at level 1. At this level, the processes are arranged in line with the supply chain strategy. The goal to be achieved at level 2 is to simplify the supply chain and increase the flexibility of the entire supply chain (Arifin et al., 2019). At this level 2, market constraints, product constraints and company constraints for developing inter and intra-company processes. Level 3 is the level of the process element and is the lowest level in the scope of the SCOR model. At the implementation level, which is a level below level 3, the process elements are broken down into tasks and advanced activities. This level of implementation does not cover the scope of the SCOR model. Level 3 allows the company to define in detail the processes identified as well as performance measures and best practices in each activity. Performance levels and practices are defined for the processes of this element. At this level, benchmarking and the required attributes are also needed to enable software. Level 3 also includes input output and basic logic flow from the process elements. At level 4, the implementation of the supply chain takes a role. At this level, the tasks in each activity required at level 3 are described in detail in order to implement and manage a daily-based supply chain (Suryanto \& Komalasari, 2019; Hamali et al., 2020; Janaki, 2019; Goodarzi \& Soltani, 2020; Ridwan et al., 2019; Mathew \& Sahu, 2018).

\section{Research Methods}

Data analysis techniques used to manage and analyse the data that has been collected consists of the following stages of data management:

\section{Calculation of SCOR Model 1 level metric performance attributes}

Calculations that are used are based on the standard calculations listed in SCOR performance as follows:

- $\quad$ Perfect Order Fulfilment (POF)

POF is the percentage of orders that are sent in full and in due time in accordance with customer requests and the goods sent do not have quality.

- $\quad$ Order Fulfilment Cycle-Time (OFCT) Fulfilment Order

OFCT is the amount of time (days) needed from the time the order is received until the product is received at the customer's place. The value of OFCT can be measured from the average number of days needed, from the customer ordering the goods to the goods reaching the customer's hands.

- Upside Supply Chain Flexibility (USCF)

USCF is the number of days needed (Process Plan, Source, Make, Delivery) to achieve a continuous unplanned increase of $20 \%$ of the number of products shipped

- Upside Supply Chain Adaptability (USCA)

USCA is presenting an increase in the maximum number of sent that can be maintained (sustainable) and can be achieved 30 days.

- Downside Supply Chain Adaptability

This is a reduction in the quantity ordered 30 days before delivery without inventory or additional costs.

- $\quad$ Supply Chain Management Cost (SCMC)

This is the direct and indirect costs for the planning, sourcing, delivery and return processes.

- $\quad$ Cost of Goods Sold (COGS)

COGS is a direct cost for material and wage costs needed to make a product. COGS is defined as Cost of Goods Sold.

- $\quad$ Cash-to-Cash Cycle Time (CTCCT)

This metric (Table 1) measures the speed at which supply chains convert inventory into money. The shorter the time required, the better the supply chain. Good companies have a short cash-to-cash cycle. Of the three (3) components, CTCCT is calculated as follows:

$\mathrm{CTCCT}=$ inventory days of supply + average days of account receivable - average days of account payable

2. Supply Chain Condition Analysis

Supply chain condition analysis is analysed using descriptive methods following the process framework defined by Van Der Vorst (2005) 


\section{Supply Chain Performance Measurement}

Performance measurement refers to SCOR modelling. Aramyan et al. (2006), states that SCOR has the advantage of being able to assess the overall performance of the supply chain in various dimensions.

\section{Improvement}

Based on performance measurement and analysis, improvement here can be divided into two main subdivisions. First, by analysing the level of importance and the relationship between performance measures. Second, gap analysis and process reengineering can improve the performance of the actual supply chain.

\section{Results and Discussion}

\subsection{Level 1 Mapping}

PT EJI in carrying out its operations applies a supply chain that involves various stages of the chain from suppliers to customers. PT EJI supply chain has 2 supply lines where the finished goods process and the second line process are called physical processes. Demand for merchandise printing needs in PT EJI is on the first track through several vendors where each vendor has a variety of products and services. The function of the vendor here is to make products and services to meet the needs of PT EJI customers. With a variety of products that are certainly useful for attracting new customers. All orders collected, are processed through the PAS (Printout Administration System) system and can then be opened by each vendor account to be further processed. In this PAS system, selection of customers who are paid or unpaid, where for online orders (Application or Website), customers must pay in advance. Whereas those who order through the Account Manager will immediately be processed according to the limit that the company has given to the customer.

Orders are sorted by marketing area to determine dispatch origin, that is, distribution centers, both suppliers and customers. The purpose of determining dispatch origin is for cost efficiency. PAS administration panel can download PO (Purchase Order) and DO (Delivery Order) and all can be printed from the system. Dispatch Origin determines vendor working time and delivery time in accordance with customer wishes, i.e. delivery expectations stated in the order processing data. Furthermore, once the process is complete, the order will be sent to the customer.

\section{Calculation of Performance Attributes for metric level 1}

Calculations that are used using the standard calculations listed in SCOR performance are as follows:

\section{Perfect Order Fulfilment (POF)}

POF is the percentage of orders that are sent in full and in due time in accordance with customer requests and the goods sent do not have quality. How to determine POF is:

Table 2

Perfect Order Fulfilment (POF)

\begin{tabular}{|c|c|c|c|c|c|c|c|c|c|}
\hline Month & $\begin{array}{l}\text { Order } \\
\text { Total }\end{array}$ & $\begin{array}{l}\text { Actual } \\
\text { Number of } \\
\text { order in } \\
\text { problem }\end{array}$ & $\begin{array}{c}\text { POF } \\
(\%)\end{array}$ & $\begin{array}{c}\text { Order } \\
\text { Total }\end{array}$ & $\begin{array}{c}\text { B2C } \\
\text { Number of } \\
\text { order in } \\
\text { problem }\end{array}$ & $\begin{array}{l}\text { POF } \\
(\%)\end{array}$ & $\begin{array}{l}\text { Order } \\
\text { Total }\end{array}$ & $\begin{array}{c}\text { B2B } \\
\text { Number of } \\
\text { order in } \\
\text { problem }\end{array}$ & $\begin{array}{l}\text { POF } \\
(\%)\end{array}$ \\
\hline January & 45 & 5 & 89 & 11 & 3 & 79 & 34 & 2 & 94 \\
\hline February & 35 & 4 & 89 & 9 & 2 & 78 & 26 & 2 & 92 \\
\hline March & 55 & 6 & 89 & 19 & 4 & 79 & 36 & 2 & 94 \\
\hline April & 74 & 7 & 91 & 14 & 3 & 79 & 60 & 4 & 93 \\
\hline May & 84 & 11 & 87 & 19 & 5 & 74 & 65 & 6 & 91 \\
\hline June & 56 & 4 & 93 & 11 & 3 & 73 & 45 & 1 & 98 \\
\hline July & 84 & 9 & 89 & 21 & 2 & 90 & 63 & 7 & 89 \\
\hline August & 104 & 14 & 87 & 29 & 7 & 76 & 75 & 7 & 91 \\
\hline September & 76 & 7 & 91 & 17 & 4 & 76 & 59 & 3 & 95 \\
\hline October & 34 & 2 & 94 & 9 & 2 & 78 & 25 & 0 & 100 \\
\hline November & 38 & 2 & 95 & 13 & 1 & 92 & 25 & 1 & 96 \\
\hline December & 51 & 5 & 90 & 16 & 2 & 88 & 35 & 3 & 91 \\
\hline & verage & & 90 & \multicolumn{2}{|c|}{ Average } & 80 & \multicolumn{2}{|c|}{ Average } & 94 \\
\hline
\end{tabular}

\section{Cycle-Time (OFCT) Fulfilment Order}

OFCT is the amount of time (days) needed from the time the order is received until the product is received at the customer's place. The value of OFCT can be measured from the average number of days needed, from the customer ordering the goods to the goods reaching the customer's hands. 
Table 3

Order Fulfilment Cycle Time (OFCT)

\begin{tabular}{|c|c|c|c|c|c|c|c|c|c|}
\hline Month & $\begin{array}{l}\text { Order } \\
\text { Total }\end{array}$ & $\begin{array}{c}\text { Actual } \\
\text { Average } \\
\text { Production } \\
\text { Time (Days) }\end{array}$ & $\begin{array}{l}\text { OFCT } \\
\text { (Day) }\end{array}$ & $\begin{array}{l}\text { Order } \\
\text { Total }\end{array}$ & $\begin{array}{c}\text { B2C } \\
\text { Average } \\
\text { Production } \\
\text { Time (Days) }\end{array}$ & $\begin{array}{l}\text { OFCT } \\
\text { (Day) }\end{array}$ & $\begin{array}{l}\text { Order } \\
\text { Total }\end{array}$ & $\begin{array}{c}\text { B2B } \\
\text { Average } \\
\text { Production } \\
\text { Time (Days) }\end{array}$ & $\begin{array}{l}\text { OFCT } \\
\text { (Day) }\end{array}$ \\
\hline January & 45 & 9 & 9 & 11 & 4 & 4 & 34 & 7 & 7 \\
\hline February & 35 & 7 & 7 & 9 & 3 & 3 & 26 & 4 & 4 \\
\hline March & 55 & 8 & 8 & 19 & 7 & 7 & 36 & 7 & 7 \\
\hline April & 74 & 12 & 12 & 14 & 5 & 5 & 60 & 11 & 11 \\
\hline May & 84 & 19 & 19 & 19 & 3 & 3 & 65 & 12 & 12 \\
\hline June & 56 & 14 & 14 & 11 & 2 & 2 & 45 & 14 & 14 \\
\hline July & 84 & 7 & 7 & 21 & 4 & 4 & 63 & 9 & 9 \\
\hline August & 104 & 9 & 9 & 29 & 7 & 7 & 75 & 7 & 7 \\
\hline September & 76 & 8 & 8 & 17 & 3 & 3 & 59 & 7 & 7 \\
\hline October & 34 & 6 & 6 & 9 & 2 & 2 & 25 & 7 & 7 \\
\hline November & 38 & 11 & 11 & 13 & 2 & 2 & 25 & 14 & 14 \\
\hline December & 51 & 14 & 14 & 16 & 3 & 3 & 35 & 9 & 9 \\
\hline & Average & & 10 & \multicolumn{2}{|c|}{ Average } & 4 & \multicolumn{2}{|c|}{ Average } & 9 \\
\hline
\end{tabular}

\section{Cost of Good Sold (COGS)}

COGS is a direct cost for material and wage costs needed to make a product. COGS is defined as Cost of Goods Sold.

Table 4

Cost of Goods Sold (COGS)

\begin{tabular}{ccccccccccccc}
\hline \multirow{2}{*}{ Month } & \multicolumn{9}{c}{ Actual } & \multicolumn{1}{c}{ B2C } & \multicolumn{1}{c}{ B2B } \\
\cline { 2 - 12 } Cales & COGS & Gross & COGS & Sales & COGS & Gross & COGS & Sales & COGS & Gross & COGS \\
\hline January & $5,966,080$ & $5,061,460$ & 904,620 & 18 & $4,135,898$ & $3,455,786$ & 680,112 & 20 & $1,830,182$ & $1,605,674$ \\
February & $1,017,826,985$ & $59,906,829$ & $257,920,156$ & 34 & $3,822,000$ & $2,110,878$ & $1,711,122$ & 81 & $1,014,004,985$ & $757,795,951$ & $56,209,034$ & 34 \\
March & $28,366,461$ & $20,045,765$ & $8,320,696$ & 42 & $2,447,500$ & $1,576,990$ & 870,510 & 55 & $25,918,961$ & $18,468,775$ & $7,450,186$ & 40 \\
April & $62,430,252$ & $45,087,553$ & $17,342,699$ & 38 & $6,322,792$ & $4,057,879$ & $2,264,913$ & 56 & $56,107,460$ & $41,029,674$ & $15,077,786$ & 37 \\
May & $214,708,770$ & $165,088,635$ & $49,620,135$ & 30 & $1,543,000$ & 985,088 & 557,912 & 57 & $213,165,770$ & $164,103,547$ & $49,062,223$ & 30 \\
June & $223,420,600$ & $176,253,192$ & $47,167,408$ & 27 & $1,852,600$ & $1,378,675$ & 473,925 & 34 & $221,568,000$ & $174,874,517$ & $46,693,483$ & 27 \\
July & $416,372,640$ & $346,604,729$ & $69,767,911$ & 20 & $1,662,480$ & $1,150,455$ & 512,025 & 45 & $414,710,160$ & $345,454,274$ & $9,255,886$ & 20 \\
August & $621,059,483$ & $525,434,183$ & $95,625,300$ & 18 & $2,599,860$ & $1,987,650$ & 612,210 & 31 & $618,459,623$ & $523,446,533$ & $5,013,090$ & 18 \\
September & $210,913,638$ & $154,236,880$ & $56,676,758$ & 37 & $3,495,496$ & $2,768,978$ & 726,518 & 26 & $207,418,142$ & $151,467,902$ & $5,950,240$ & 37 \\
October & $128,783,913$ & $78,664,233$ & $50,119,680$ & 64 & $3,179,250$ & $2,050,367$ & $1,128,883$ & 55 & $125,604,663$ & $76,613,866$ & $8,990,797$ & 64 \\
November & $126,270,070$ & $76,559,087$ & $49,710,983$ & 65 & $4,341,492$ & $2,857,354$ & $1,484,138$ & 52 & $121,928,578$ & $73,701,733$ & $48,226,845$ & 65 \\
December & $459,808,487$ & $325,588,834$ & $134,219,653$ & 41 & $2,280,484$ & $1,347,967$ & 932,517 & 69 & $457,528,003$ & $324,240,867$ & $33,287,136$ & 41 \\
\hline Total & $3,515,927,379$ & 2.678 .531 .380 & $837,395,999$ & 31 & $37,682,852$ & $25.728,067$ & $11,954,785$ & 46 & $3,478,244,527$ & $2,652,803,313$ & $825,441,214$ & 31 \\
\hline
\end{tabular}

\section{Cash-to-Cash Cycle Time (CTCCT)}

CTCCT, this metric measures the speed of supply chains turning inventory into money. The shorter the time required, the better the supply chain. Good companies have a short cash-to-cash cycle. Of the three (3) components, CTCCT is calculated as follows:

CTCCT = inventory days of supply + average days of account recivable - average days of account payable

Table 5

Cash To Cash Cycle Time (CTCCT)

\begin{tabular}{|c|c|c|c|c|c|c|c|c|c|c|c|c|}
\hline \multirow[b]{2}{*}{ Month } & \multicolumn{4}{|c|}{ Actual } & \multicolumn{4}{|c|}{$\mathrm{B} 2 \mathrm{C}$} & \multicolumn{4}{|c|}{ B2B } \\
\hline & $\begin{array}{l}\text { Days } \\
\text { Supply } \\
\text { (Days) }\end{array}$ & $\begin{array}{c}\text { Average Days } \\
\text { of Account } \\
\text { Receiveable } \\
\text { (Days) }\end{array}$ & $\begin{array}{c}\text { Average } \\
\text { Days of } \\
\text { Account } \\
\text { Payable } \\
\text { (Days) }\end{array}$ & $\begin{array}{c}\text { CTCCT } \\
\text { (Days) }\end{array}$ & $\begin{array}{l}\text { Days } \\
\text { Supply } \\
\text { (Days) }\end{array}$ & $\begin{array}{c}\text { Average Days } \\
\text { of Account } \\
\text { Receiveable } \\
\text { (Days) }\end{array}$ & $\begin{array}{c}\text { Average } \\
\text { Days of } \\
\text { Account } \\
\text { Payable } \\
\text { (Days) }\end{array}$ & $\begin{array}{l}\text { CTCCT } \\
\text { (Days) }\end{array}$ & $\begin{array}{l}\text { Days } \\
\text { Supply }\end{array}$ & $\begin{array}{c}\text { Average Days } \\
\text { of Account } \\
\text { Receiveable } \\
\text { (Days) }\end{array}$ & $\begin{array}{c}\text { Average } \\
\text { Days of } \\
\text { Account } \\
\text { Payable } \\
\text { (Days) }\end{array}$ & $\begin{array}{c}\text { CTCCT } \\
\text { (Days) }\end{array}$ \\
\hline January & 4 & 4 & 24 & 16 & 4 & 7 & 1 & 10 & 7 & 8 & 45 & 30 \\
\hline February & 3 & 3 & 35 & 29 & 3 & 4 & 2 & 5 & 4 & 14 & 36 & 18 \\
\hline March & 7 & 6 & 28 & 15 & 7 & 7 & 2 & 12 & 7 & 21 & 45 & 17 \\
\hline April & 5 & 4 & 24 & 15 & 5 & 11 & 1 & 15 & 11 & 11 & 30 & 8 \\
\hline May & 3 & 2 & 32 & 27 & 3 & 12 & 2 & 13 & 12 & 13 & 28 & 3 \\
\hline June & 2 & 5 & 21 & 14 & 2 & 14 & 2 & 14 & 14 & 21 & 45 & 10 \\
\hline July & 4 & 6 & 18 & 8 & 4 & 9 & 2 & 11 & 9 & 19 & 36 & 8 \\
\hline August & 7 & 5 & 24 & 12 & 7 & 7 & 2 & 12 & 7 & 27 & 45 & 11 \\
\hline September & 3 & 7 & 21 & 11 & 3 & 7 & 1 & 9 & 7 & 32 & 60 & 21 \\
\hline October & 2 & 3 & 19 & 14 & 2 & 7 & 2 & 7 & 7 & 23 & 45 & 15 \\
\hline November & 2 & 4 & 28 & 22 & 2 & 14 & 1 & 15 & 14 & 8 & 32 & 10 \\
\hline Average & 4 & 5 & 25 & 17 & 4 & 9 & 2 & 11 & 9 & 18 & 41 & 14 \\
\hline
\end{tabular}


PT EJI Supply Chain is measured by level 1 (one) performance metric, namely the performance of PT EJI delivery. Bolstorff (2003) explains that level 1 (one) analysis begins by defining the company's business goals. This is done so that the supply chain performance evaluation will be carried out in line with the company's strategy and focus on the main objectives to be achieved. Based on company data we can know that the business objectives of PT EJI are defined as follows:

1. Providing the Best Service (Diverse products, transparent prices and cheap delivery)

2. Increase company profits.

After knowing the business objectives above, the next step is to measure the metrics in SCOR according to the business objectives. Based on calculations, the metrics provided by SCOR can be seen in the actual data column in Table 6 . For the first business purpose (1), the available data are POF and OFCT. While for the second purpose (2), it is COGS and CTCCT.

Table 6

SCOR Model Level 1 metrics

\begin{tabular}{|c|c|c|c|c|c|c|}
\hline Performance Attribute & Level 1 Metric & $\begin{array}{l}\text { Actual Data } \\
\text { (a) }\end{array}$ & $\begin{array}{l}\mathrm{B} 2 \mathrm{C} \\
\text { (b) }\end{array}$ & $\begin{array}{l}\mathrm{B} 2 \mathrm{~B} \\
\text { (c) }\end{array}$ & Requirement gap & Opportunity \\
\hline $\begin{array}{l}\text { Supply Chain } \\
\text { Reliability }\end{array}$ & POF $(\%)$ & 90 & 80 & 94 & 4 & $(780,738,796)$ \\
\hline $\begin{array}{c}\text { Supply Chain } \\
\text { Responsiveness }\end{array}$ & OFCT (Day) & 10 & 4 & 9 & 6 & Increase \\
\hline \multirow[t]{2}{*}{ Supply Chain Cost } & SCM Cost & $\mathrm{N} / \mathrm{A}$ & $\mathrm{N} / \mathrm{A}$ & $\mathrm{N} / \mathrm{A}$ & $\mathrm{N} / \mathrm{A}$ & $\mathrm{N} / \mathrm{A}$ \\
\hline & COGS $(\%)$ & 31 & 46 & 31 & 15 & $(663,627,976)$ \\
\hline \multirow{2}{*}{$\begin{array}{c}\text { Supply Chain Asset } \\
\text { Management }\end{array}$} & CTCCT (Day) & 17 & 11 & 14 & 4 & $\begin{array}{c}\text { Reduce interest } \\
\text { expense }\end{array}$ \\
\hline & $\begin{array}{l}\text { Return on Supply } \\
\text { Chain Asset }\end{array}$ & $\mathrm{N} / \mathrm{A}$ & $\mathrm{N} / \mathrm{A}$ & $\mathrm{N} / \mathrm{A}$ & $\mathrm{N} / \mathrm{A}$ & $\mathrm{N} / \mathrm{A}$ \\
\hline
\end{tabular}

After getting the actual data and calculating based on the four (4) metrics, the next step is to determine the actual position and determine the target performance for each metric based on benchmark data. Benchmark data are used to determine target performance, giving an overview of the magnitude of the gap between company performance. Benchmark data is used as a reference in benchmarking data and performance trends from year to year, and helps in directing the development of supply chains. Benchmark values continue to assume the target to be achieved for the next year. Based on Table 7, it can be seen that business objectives provide the best level of service. In the SCOR Model, it is not recommended that there be more than one business objective with target performance in the B2C position. The complex scope of supply chain development requires restrictions on $\mathrm{B} 2 \mathrm{C}$, so that improvement efforts are made on only one business objective. After determining the target performance, the next step is to conduct a gap analysis aimed at calculating the magnitude of the difference between the actual and targeted conditions. The magnitude of the difference translates into an increase in income, if the performance is improved until it reaches the target (Bolstorff \& Rosenbeum, 2003). In Table 7, it can be seen the amount of gap analysis, where the B2C column is filled with the magnitude of the increase in income, if the performance for these metrics is improved to reach the targeted position. To calculate the opportunity, we need the total value of revenue and the percentage of gross profit generated (Bolstorff \& Rosenbeum, 2013)

Table 7

Calculation of B2C \& B2 B opportunities for POF with LOM

\begin{tabular}{|c|c|c|}
\hline \multirow{2}{*}{ Component } & \multicolumn{2}{|c|}{ The calculation results } \\
\hline & B2C & B2B \\
\hline Total Revenue (Rp) & $3,515,927,379$ & $3,515,927,379$ \\
\hline Current POF (\%) & 90 & 90 \\
\hline Target POF (B2C); \% & 80 & 94 \\
\hline Total Revenue x ((Actual 100-POF) / 100); Rp & $344,215,476$ & $344,215,475.61$ \\
\hline Total Revenue x ((100-POF Target) / 100); Rp & $718,334,293$ & $220,772,384.71$ \\
\hline Difference (a) and (b); Rp & $374,118,817$ & $123,443,091$ \\
\hline Gross profit & $209 \%$ & $64 \%$ \\
\hline Gross Profit x Difference (Opportunity); Rp & $780,738,796$ & $79,173,737$ \\
\hline
\end{tabular}

The magnitude of the difference based on gap analysis is presented in Table 7, where the opportunity column is filled with the size of the income level, if the performance for the metrics is increased to the targeted position. To calculate the opportunity, we need the total value of revenue and the percentage of gross profit generated. However, due to confidential financial data, the magnitude of opportunity is calculated using a number of approaches. First, gross profit is taken from the data of the last 1 year, which is divided into 4 quarters. Q1-Q4 2018. Total revenue is calculated in the last one (1) year. In this case, there are several methods in the SCOR Model that can be used to calculate the amount of opportunity for 
POF. One method used in this method is LOM (Bolstroff \& Rosenbeum, 2003). With this method we can find out the magnitude of lost opportunity to earn certain income based on the current performance of POF and COGS, where as for the calculations in Table 7. The magnitude of opportunity for OFCT metrics in achieving targets is in line with the opportunities that come from POF. If OFCT is lower, it means that the waiting time is getting shorter, then automatically makes the POF value higher and has an impact on increasing revenue. Opportunity for the COGS metric is obtained by calculating the amount of COGS decrease when the reduction target has been reached. The decrease directly signifies an increase in gross profit (Nguyena et al., 2020).

\subsection{Level 2 Mapping}

Each core process in SCOR is presented in more detail from three types of SCOR processes, namely Planning, Execution and Enable. Level 2 supply chain review aims to detail the identification of the calculated metric values. Mapping level two (2) can be seen in the following figure:

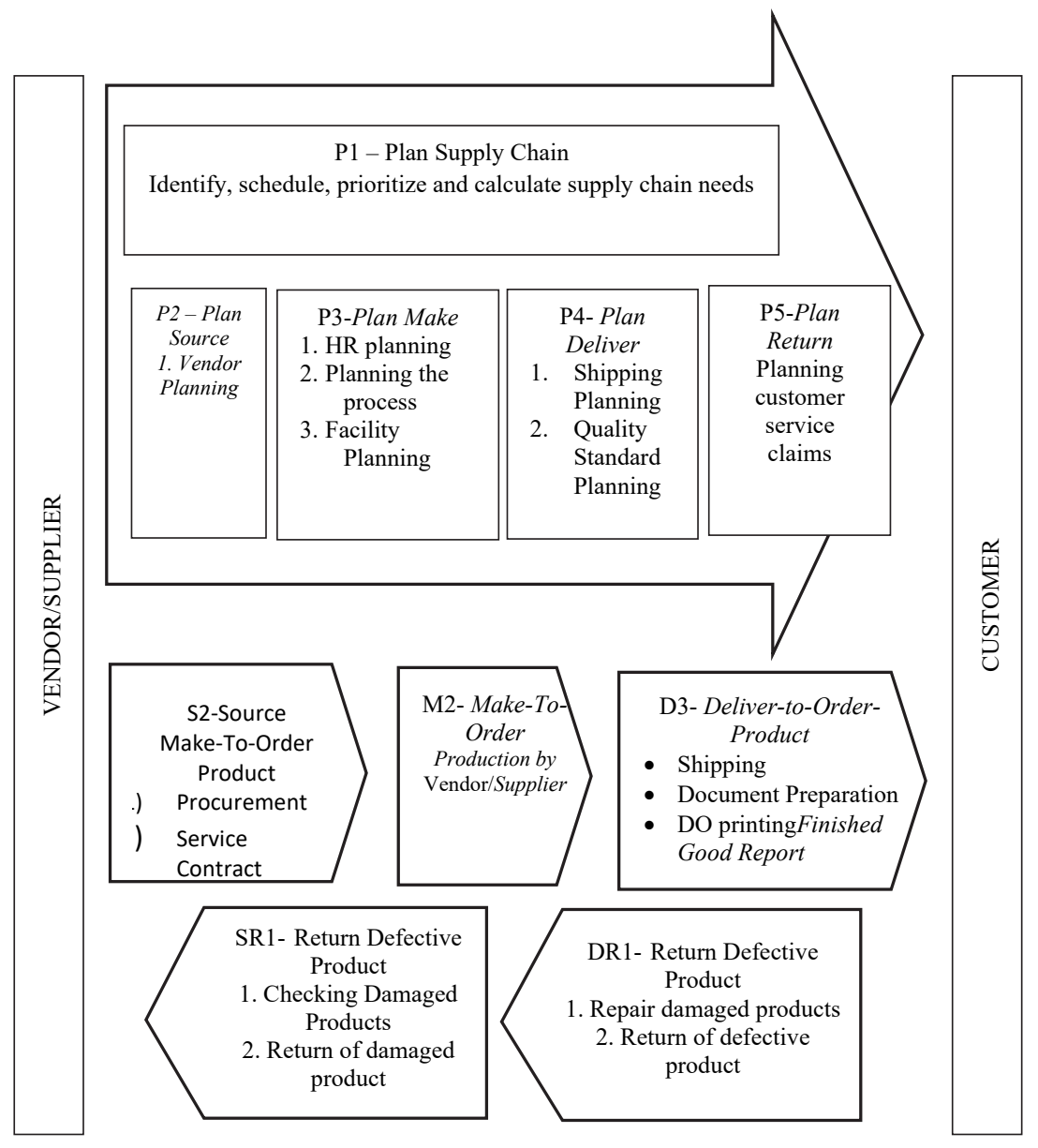

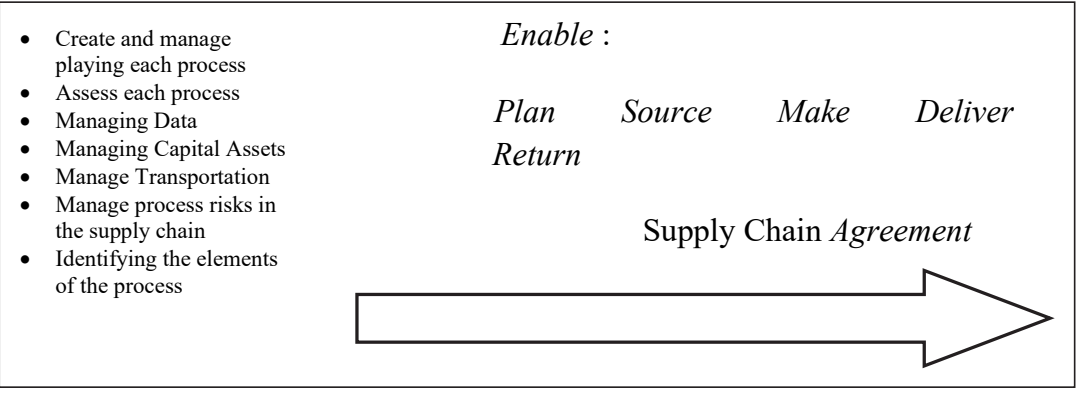

Fig. 1. Mapping Level 2 Merchandise Product Supply Chain 
In calculating POF and OFCT, it is necessary to pay attention to on time, quantitative accuracy (in full) and the completeness of supporting documents, and the condition of goods in perfect condition. If any of the above conditions are not met, then the services provided by PT EJI are not good. Based on conditions that have occurred in the past 1 (one) year, it is known that the cause of imperfections in fulfilling orders is due to the delivery of goods that are not on time (not in time).

Table 8

POF and OFCT values in Deliver, Make and Source processes

\begin{tabular}{cccc}
\hline Metric & Deliver & Make & Source \\
\hline POF (\%) & 80 & 99 & 95 \\
OFCT (Day) & 4 & 7 & 2 \\
\hline
\end{tabular}

Based on these three values, it appears that the delivery process has the lowest performance. Presentation Value (\%) POF in the delivery process we can know that has a value of $80 \%$ and OFCT 4 Days, this data can be seen in the column table of POF and OFCT values. Inaccurate delivery by PT EJI as a whole can hamper the company's business goals, namely: providing the best service. Henceforth, level 3 (three) mapping can be done.

\subsection{Level 3 Mapping}

A level 3 mapping analysis is carried out to see even more detail than processes that have lower performance values based on level 2 analysis. This is so that we can find out the next process for improvisation. Level mapping (3) is carried out on all activities in the delivery process, which can be seen in level 3 (three) mapping.

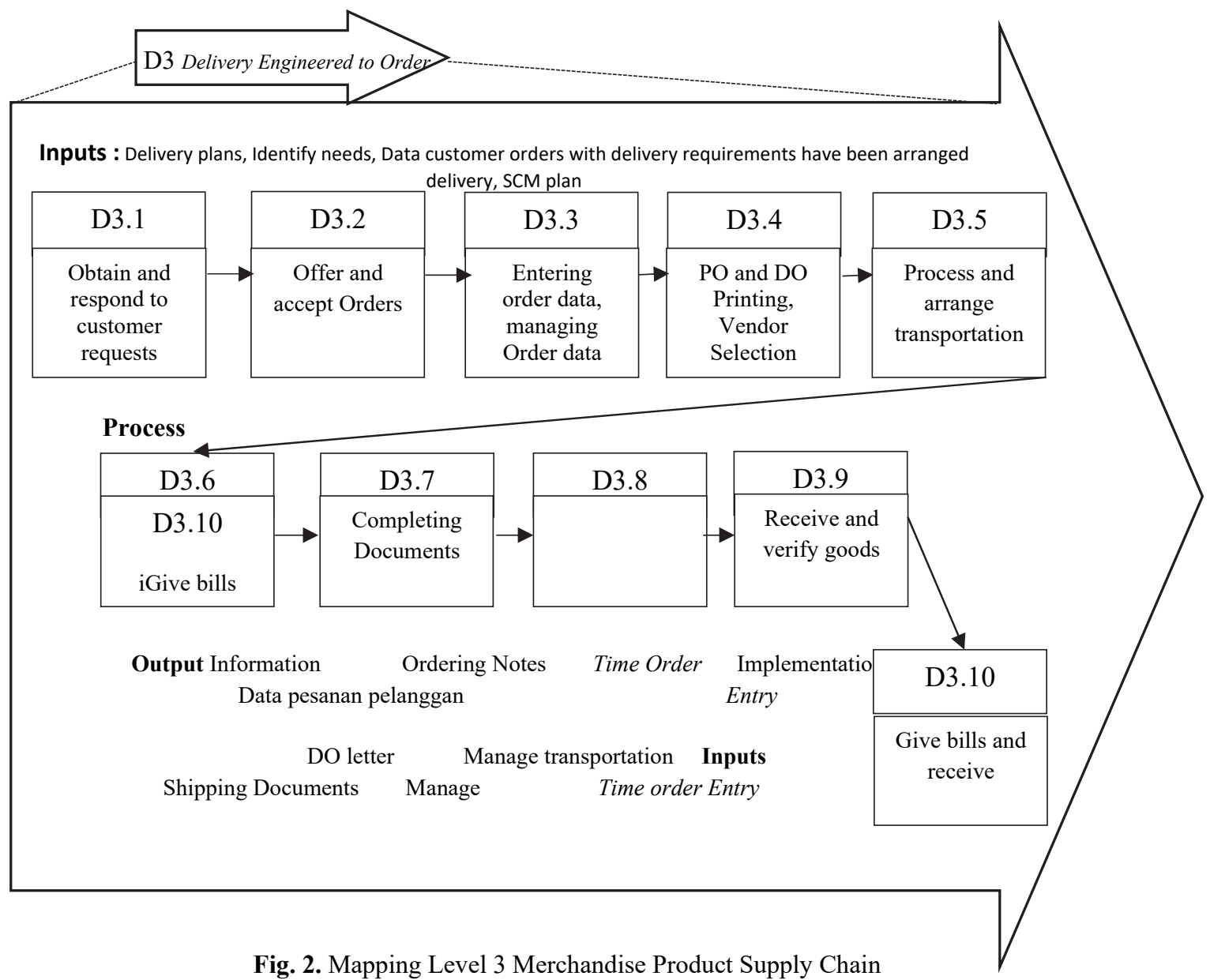

The cause of the delivery of goods that are not timely starts from downstream to upstream can be traced to the process of delivery, make and source. In the process of delivery, the process elements in the delivery often experience problems so that delivery is hampered. It can also be seen that an $80 \%$ POF value on delivery is obtained from an estimate of what percentage of the accuracy of the shipment of goods in terms of the quantity in accordance with the demand for goods. While the OFCT score is around 4 (four) days. This figure is obtained from the average delivery of goods to the customer in accordance with the expectations of shipping to the customer. In the make process the POF value is almost $100 \%$. This figure is obtained based on estimates of what percentage of the needs that can be met by the vendor. This is also supported 
by the location of the Vendor with the customer. A POF value of around $95 \%$ in the Source process is obtained based on an estimate of what percentage of the number of orders the vendor can fulfil to customers.

\section{Improvement}

Improvement is done by brainstorming with the TopLevel Management of PT. EJI. Where during the discussion the researcher explained the results and previous discussions to the Top Level Management of PT. EJI. The results of the brainstorming accomplished is the Top Level Management PT. EJI will fix the performance of the process of delivering the following:

1. Separate from sending routes by adding couriers to support shipping both Online and Offline This is done because for now the couriers at PT EJI only amount to 1 person and load from the couriers on every day full delivery from morning to night. This decision was taken because in addition to separate between the delivery of offline / online also helps to speed so fast goods deliver.

2. The existence of QC on invoice documents by PT EJI admin finance to avoid incomplete documents.

QC documents are very necessary at the time of delivery because it allows the documents that we send to each company have different procedures, therefore the admin must crosscheck the documents to be sent.

3. Delivery SOP is made so that the shipping process can be delivered in accordance with the specified address. SOPs for shipments are made to help the relevant teams profiling product data that has been delivered and invoiced.

4. Provide Inchiet at the time of delivery to avoid mismatching goods.

For certain items, the diet will be given a diet instead of printed products, where the diet is to avoid deficiencies of the products that have been transferred. The number of inches given is around $5 \%$ of the quantity of goods or 1 3 pcs for merchandise products.

\section{Conclusions}

After the collection, management, analysis and discussion of this research, the conclusion is as follows,

1. Metric or supply chain performance measurement indicators for PT. EJI used for measurement using the SCOR Model which consists of 4 performance criteria attributes consisting of 1 metric level used as an indicator. Based on the level of importance as follows:

1. Reliability: Perfect Order Fulfilment (POF)

2. Responsiveness: Order Fulfilment Cycle Time (OFCT)

3. Cost: Cost Of Goods Sold (COGS)

4. Assets: Cash to Cash Cycle Time (CTCCT)

2. The results of the performance measurement show that the delivery process is 80.0 , where the value is the lowest compared to other metrics, namely Make 99.0 and Source 95.0. Recommendations for improvement in Supply Chain are to improve delivery by separating shipping routes for Online and Offline shipping, checking the quality of invoice documents to avoid incomplete documents, making SOP for shipping, and providing a diet at the time of delivery to avoid mismatching goods.

\section{Acknowledgement}

The authors would like to thank the anonymous referees for constructive comments on earlier version of this paper.

\section{References}

Alzoubi, H., Ahmed, G., Al-Gasaymeh, A., \& Kurdi, B. (2020). Empirical study on sustainable supply chain strategies and its impact on competitive priorities: The mediating role of supply chain collaboration. Management Science Letters, 10(3), 703-708.

Arifin, M., Ibrahim, A., \& Nur, M. (2019). Integration of supply chain management and tourism: An empirical study from the hotel industry of Indonesia. Management Science Letters, 9(2), 261-270.

(2012). Supply chain operations reference model, Supply Chain Council, Inc.USA. Diakses pada website:

\section{http://www.supply-chain.org.}

Basheer, M., Siam, M., Awn, A., \& Hassan, S. (2019). Exploring the role of TQM and supply chain practices for firm supply performance in the presence of information technology capabilities and supply chain technology adoption: A case of textile firms in Pakistan. Uncertain Supply Chain Management, 7(2), 275-288.

Bayer. C. (2010). Supply Chain Operation Reference (SCOR) Model version 10.0. Supply Chain Council. 
Bolstorff, P., \& Rosenbeum, R. (2003). Supply Chain Excellence: A Handbookfor Dramatic Improvement Using The SCOR Model. New York: AMACOM.

Chow, H. K., Choy, K. L., Lee, W. B., \& Lau, K. C. (2006). Design of a RFID case-based resource management system for warehouse operations. Expert systems with applications, 30(4), 561-576.

Georgise, F. B., Thoben, K. D., \& Seifert, M. (2013). Implementing the SCOR model best practices for supply chain improvement in developing countries. International Journal of u-and e-Service, Science and Technology, 6(4), 13-25.

Ghassemi, A., Asl-Najafi, J., \& Yaghoubi, S. (2018). A dynamic bi-objective closed-loop supply chain network design considering supplier selection and remanufacturer subcontractors. Uncertain Supply Chain Management, 6(2), 117-134.

Global SCC Benchmark. (2010). The American Productivity and Quality Center. USA. Diakses pada website : http://www.apqc.org

Global Supply Chain Benchmark Report. (2006). Aberdeen Group, USA. Diakses pada website : http://www.aberdeen.com

Goodarzi, M., \& Soltani, Z. (2020). Applying the FDEMATEL technique in developing and prioritizing strategies of economic participation development in urban management of Ahvaz Metropolis. Management Science Letters, 10(13), 3063-3070.

Ul-Hameed, W., Mohammad, H., Shahar, H., Aljumah, A., \& Azizan, S. (2019). The effect of integration between audit and leadership on supply chain performance: Evidence from UK based supply chain companies. Uncertain Supply Chain Management, 7(2), 311-328.

Hamali, S., Prihandoko, D., Kurniawan, S., \& Ramdhani, R. (2020). The effects of supply chain information integration on organizational performance in food small industry. Management Science Letters, 10(3), 695-702.

Heizer, J., \& B. Render. (2008). Manajemen Operasi (Terjemahan). Jakarta: Salemba Empat.

Irfan, D., Xiaofei, X., \& Chun, D. S. (2008). A SCOR Reference Model of the Supply Chain Management System in an Enterprise. International Arab Journal of Information Technology (IAJIT), 5(3).

Jamehshooran, B. G., Shaharoun, M., \& Haron, H. N. (2015). Assessing supply chain performance through applying the SCOR model. International Journal of Supply Chain Management, 4(1), 1-11.

Janaki, D. (2019). Adapting the SCOR model for supply chain network assessment and improvement in oil industry. International Journal of Data and Network Science, 3(4), 331-338.

Kasi, V. (2005). Systemic Assessment of SCOR for Modeling Supply Chains. Proceedings of the 38th Hawaii International Conference on System Sciences, 1-10.

Kosasih, K., Wibowo, W \& Saparuddin, S. (2020). The influence of ambidextrous organization and authentic followership on innovative performance: The mediating role of change readiness. Management Science Letters, 10(7), 1513-1520.

Mathew, M., \& Sahu, S. (2018). Comparison of new multi-criteria decision making methods for material handling equipment selection. Management Science Letters, 8(3), 139-150.

Maulidiya, N. S., Setyanto, N. W., \& Yuniarti, R. (2014). Pengukuran Kinerja Supply Chain Berdasarkan Proses Inti Pada Supply Chain Operation Reference (SCOR)(Studi Kasus Pada PT Arthawenasakti Gemilang Malang). Jurnal Rekayasa dan Manajemen Sistem Industri, 2(4), 696-705.

Mutakin, A., \& Hubeis, M. (2011). Pengukuran kinerja manajemen rantai pasokan dengan SCOR model 9.0 (Studi kasus di PT Indocement Tunggal Prakarsa Tbk). Jurnal manajemen dan Organisasi, 2(3), 89-103.

Nguyena, T. T. H., Phamb, T. T. H., Lec, Q. B., Phamd, T. T. H., Buie, T. V. A., \& Nguyenf, T. Q. A. (2020). Impact of corporate social responsibility on organizational commitment through organizational trust and organizational identification.

Pires, S. R., Bremer, C. F., De Santa Eulalia, L. A., \& Goulart, C. P. (2001). Supply chain and virtual enterprises: comparisons, migration and a case study. International Journal of Logistics, 4(3), 297-311.

Pujawan, I N. (2005). Supply Chain Management. Edisi pertama. Surabaya: Guna Widya.

Rahayu, P., \& Kusumah, L. H. (2017). Pengukuran Kinerja Aktifitas Supply Chain Pada Industri Minuman Jus dengan SCOR (Study Kasus PT. API). Prosiding SENIATI, C39-1.

Rakhman, A., Machfud, M., \& Arkeman, Y. (2018). Kinerja Manajemen Rantai Pasok dengan Menggunakan Pendekatan Metode Supply Chain Operation Reference (SCOR). Jurnal Aplikasi Bisnis dan Manajemen (JABM), 4(1), 106.

Ridwan, M., Asnawi, N., \& Sutikno, S. (2019). Zakat collection and distribution system and its impact on the economy of Indonesia. Uncertain Supply Chain Management, 7(4), 589-598.

Simchi-Levi, D., Kaminsky, P., \& Simchi-Levi, E. (2000). Designing and Managing the Supply Chain, Irwin, Homewood.

Suryanto, T., \& Komalasari, A. (2019). Effect of mandatory adoption of international financial reporting standard (IFRS) on supply chain management: A case of Indonesian dairy industry. Uncertain Supply Chain Management, 7(2), 169178.

Sutawijaya, A. H. \& Marlapa, E. (2016). Supply Chain Management: Analisis Dan Penerapan Menggunakan Reference (Scor) Di Pt. Indoturbine. MIX: Jurnal Ilmiah Manajemen, 6(1), 121-138.

Wahyuniardi, R. Syarwani, M. dan Anggani, R. (2017). Pengukuran Kinerja Supply Chain Dengan Pendekatan Supply Chain Operation References (SCOR). Jurnal Ilmiah Teknik Industri, 16(2), 123-132.

Wibowo, M. A., \& Sholeh, M. N. (2015). The analysis of supply chain performance measurement at construction project. Procedia Engineering, 125, 25-31.

Zhou, H., Benton Jr, W. C., Schilling, D. A., \& Milligan, G. W. (2011). Supply chain integration and the SCOR model. Journal of Business Logistics, 32(4), 332-344. 
(C) 2020 by the authors; licensee Growing Science, Canada. This is an open access article distributed under the terms and conditions of the Creative Commons Attribution (CC-BY) license (http://creativecommons.org/licenses/by/4.0/). 